\title{
Appearing and disappearing CT scan abnormalities and seizures
}

\author{
PK SETHI, BR KUMAR, VS MADAN, V MOHAN \\ From the Neurological Centre, Army Hospital, Delhi, India
}

SUMMARY A group of patients presenting with seizures (focal or generalised) and abnormal CT scans who, on follow up, showed complete resolution of the CT scan changes, without any treatment other than anticonvulsants, are described.

Seizures may be due to idiopathic epilepsy or be symptomatic of an underlying disorder which may be revealed by computed tomography $(\mathrm{CT})$. Possible scan abnormalities include: congenital disorder (birth injury and infarction), trauma, tumour, infection (abscess, encephalitis, tuberculosis, toxoplasmosis, cysticercosis), vascular disease and degenerative disorders.' ${ }^{\prime}$ These CT abnormalities are expected to persist, increase or leave some evidence of the original lesion in follow up scans unless some specific treatment is given in treatable cases. We report patients presenting with seizures in which initial CT scans were abnormal, but on follow up CT scans these abnormalities had disappeared with no specific treatment except anticonvulsants.

\section{Materials and methods}

Eleven cases, seen in the epilepsy clinic of our neurological centre in the past year had initial CT scan abnormalities that completely disappeared over the next 6 to 24 weeks with no treatment except anticonvulsants.

\section{Case reports}

The table summarises the clinical data from eleven cases. In the following three cases the sequence of events surrounding the seizure and the follow up are described.

\section{Case 1}

A 14-year-old boy, product of term delivery with a history suggestive of slight hypoxia at birth, was well till the morning of 26 June 1983, when he had clonic movements of the right toes with Jacksonian extension on the right side, later

Address for reprint requests: Lt Col PK Sethi VSM, Army Hospital, Delhi Cantt 110010, India.

Received 25 September 1984 and in revised form 14 December 1984.

Accepted 24 December 1984
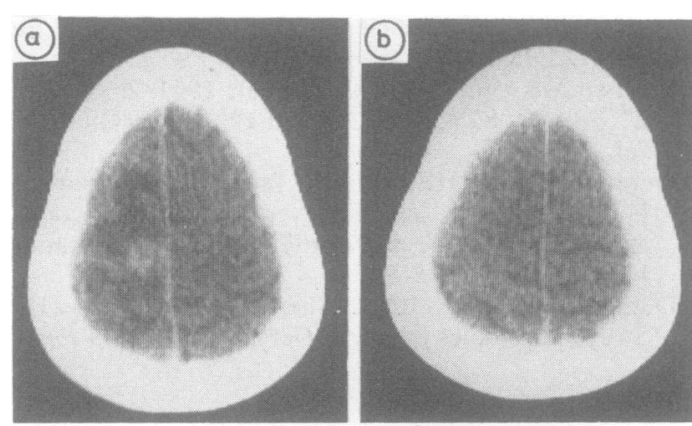

Fig 1 Enhanced Scans. (a) There is a small area of increased attenuation value in left parietal parasagittal region with significant perifocal oedema. (b) Follow up CF showed complete disappearance of the lesion.

becoming generalised with loss of consciousness. On 10 August, he had three similar episodes of focal seizures starting on the right side but with no generalisation or loss of consciousness. On 26 August he had another such episode following which he had weakness of right foot. There was a partial right foot drop, and the right knee jerk was brisk. Fundi were normal. Blood count, urinalysis, skull, chest and thigh radiographs, blood chemistry and awake EEG were all normal. CT scan on 26 August 1983 showed a small area of increased attenuation value in the left perasagittal region with significant perifocal oedema (fig 1a). He was given phenobarbitone $30 \mathrm{mgm}$ morning and $60 \mathrm{mgm}$ at night. The weakness of the right foot and leg completely disappeared over the next two weeks and he remained seizure free. A repeat CT scan on 1 February 1984 was normal (fig 1b).

\section{Case 2}

A $4 \frac{1}{2}$ year-old boy, a product of a normal term delivery was well till the evening of 7 September 1983 when he had clonic motor seizures involving the left arm. He had six or seven seizures in one hour and developed mild postictal weakness of the left arm. Temperature was $99.8^{\circ} \mathrm{F}$ and fundi were normal. Blood count, urinalysis, blood chemistry, skull radiography and CSF examination were normal. 


\begin{tabular}{|c|c|c|c|c|c|c|}
\hline ise No & Age (yr) & $\operatorname{Sex}$ & Clinical presentation & $E E G$ & $C T$ scan abnormality & Follow up \\
\hline 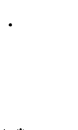 & 14 & $\mathbf{M}$ & $\begin{array}{l}\text { Rt Jacksonian seizures starting from } \\
\text { (Rt) toe, postictal Rt foot drop. } \\
\text { First seizure } 26 \text { June } 83 \text {. Last } \\
\text { seizure } 26 \text { Aug } 83 \text { at time } \\
\text { of CT scan. }\end{array}$ & NAD & $\begin{array}{l}\text { Small attenuation left parasagittal } \\
\text { region with perifocal oedema. } \\
\text { (CT } 26 \text { Aug 83). }\end{array}$ & $\begin{array}{l}\text { Asymptomatic } \\
\text { CT abnormality } \\
\text { cleared } \\
\text { (01 Feb 84). }\end{array}$ \\
\hline${ }^{*}$ & $41 / 2$ & $\mathbf{M}$ & $\begin{array}{l}\text { Repeated Lt focal motor seizures } \\
\text { Postictal Lt side weakness. First } \\
\text { seizure } 7 \text { Sept } 83 \text {. }\end{array}$ & $\begin{array}{l}\text { Generalised burst } \\
\text { of spike/slow } \\
\text { discharges. }\end{array}$ & $\begin{array}{l}\text { Low attenuation lesion Lt fronto- } \\
\text { parietal region. (CT } 14 \text { Sept } 83 \text { ). }\end{array}$ & $\begin{array}{l}\text { Asymptomatic CT } \\
\text { cleared } \\
\text { (12 Feb 84). }\end{array}$ \\
\hline & 34 & $\mathbf{F}$ & $\begin{array}{l}\text { Generalised seizures with headache } \\
\text { and vomiting prolonged postictal } \\
\text { confusion and (Rt) hand weakness. } \\
\text { First seizure } 16 \text { Oct } 83 \text {, repeat } \\
18 \text { Oct } 83 \text {. }\end{array}$ & $\begin{array}{l}\text { Slowing Lt sided } \\
\text { leads monopolar } \\
\text { run with spikes. }\end{array}$ & $\begin{array}{l}\text { High attenuating lesion with perifocal } \\
\text { oedema in (Lt) post-temporal } \\
\text { region. (CT } 28 \text { Oct } 83 \text { ). }\end{array}$ & $\begin{array}{l}\text { Asymptomatic CT } \\
\text { abnormality } \\
\text { cleared } \\
\text { (27 Apr } 84)\end{array}$ \\
\hline${ }^{*}$ & 14 & $\mathbf{F}$ & $\begin{array}{l}\text { Rt focal seizures with speech arrest } \\
\text { and later generalisation. Birth } \\
\text { history prolonged labour, hypoxia } \\
\text { at birth. First seizure } 3 \text { Aug } 83 \text {. }\end{array}$ & $\begin{array}{l}\text { Generalised burst } \\
\text { of spike/slow } \\
\text { wave discharges. }\end{array}$ & $\begin{array}{l}\text { Decrease attenuation in left parietal } \\
\text { region. (CT } 6 \text { Aug 83). }\end{array}$ & $\begin{array}{l}\text { Asymptomatic CT } \\
\text { repeated } \\
17 \text { Oct } 83 \text {. No } \\
\text { abnormality. }\end{array}$ \\
\hline & 33 & $F$ & $\begin{array}{l}\text { Lt Focal motor seizures } 6 \text { episodes, } \\
\text { no postictal weakness. First } \\
\text { seizure } 11 \text { Sept } 83 \text {, later five } \\
\text { more. Last episode } 27 \text { Nov } 83 \text {. }\end{array}$ & $\begin{array}{l}\text { Brief episodes of } \\
\text { generalised } \\
\text { bursts of slow } \\
\text { waves } 4-5 \mathrm{~Hz} \text {. }\end{array}$ & $\begin{array}{l}\text { Small high attenuation lesion with } \\
\text { perifocal oedema. Left temporal } \\
\text { region. (CT } 17 \mathrm{Dec} 83 \text { ). }\end{array}$ & $\begin{array}{l}\text { Asymptomatic. } \\
\text { Repeated CT } \\
\text { (3 Mar 84) } \\
\text { clear. }\end{array}$ \\
\hline & 30 & $\mathbf{M}$ & $\begin{array}{l}\text { Focal seizure in form of speech } \\
\text { difficulties with turning of head } \\
\text { neck to right. Solitary seizure } \\
09 \text { July } 83 \text {. }\end{array}$ & $\begin{array}{l}\text { Left temporal } \\
\text { lobe epilepto- } \\
\text { genic activity. }\end{array}$ & $\begin{array}{l}\text { High attenuating lesion with perifocal } \\
\text { oedema left temporal region } \\
\text { (CT } 22 \text { July 83). }\end{array}$ & $\begin{array}{l}\text { Asymptomatic. } \\
\text { CT clear } \\
\text { (27 Sep 83). }\end{array}$ \\
\hline & 50 & $\mathbf{M}$ & $\begin{array}{l}\text { Generalised tonic/clonic convulsions } \\
3 \text { episode in one month. First } \\
\text { seizure } 11 \text { Dec } 82 \text { and last } \\
14 \text { Jan } 83 \text {. }\end{array}$ & $\begin{array}{l}\text { Left fronto- } \\
\text { temporal } \\
\text { dysrhythmia. }\end{array}$ & $\begin{array}{l}\text { Low attenuation in post temporal } \\
\text { region. (CT } 31 \text { Jan } 83 \text { ). }\end{array}$ & $\begin{array}{l}\text { Asymptomatic CT } \\
\text { clear } \\
\text { (18 Mar 83). }\end{array}$ \\
\hline & 6 & $\mathbf{F}$ & $\begin{array}{l}\text { Focal motor seizure starting from } \\
\text { Lt hand with generalisation } 3 \\
\text { episode } 25 \text { Mar } 83 \text { and last } \\
25 \text { Apr } 83 \text {. }\end{array}$ & Normal EEG. & $\begin{array}{l}\text { Right parietal high attenuated } \\
\text { shadow surrounded with low } \\
\text { attenuation area. (CT } 25 \text { Apr 83). }\end{array}$ & $\begin{array}{l}\text { Asymptomatic. } \\
\text { Repeat CT } \\
\text { clear } \\
\text { (23 June } 83 \text { ). }\end{array}$ \\
\hline & 39 & $\mathbf{M}$ & $\begin{array}{l}\text { Two transient episodes fecling left } \\
\text { hand larger followed by episode } \\
\text { of blankness. First episode } 5 \text { Mar } 83 \\
\text { and last } 6 \text { Mar } 83 \text {. }\end{array}$ & $\begin{array}{l}\text { Normal EEG/ } \\
\text { angiogram } \\
\text { normal. }\end{array}$ & $\begin{array}{l}\text { Decrease attenuation } R \text { t parietal } \\
\text { region (CT } 19 \text { Mar 83). }\end{array}$ & $\begin{array}{l}\text { Asymptomatic } \\
\text { Repeat CT } \\
\text { clear } \\
\text { ( } 3 \text { May } 83 \text { ). }\end{array}$ \\
\hline$t$ & 58 & $\mathbf{M}$ & $\begin{array}{l}\text { Episode of vacant look followed by } \\
\text { generalised with head and neck } \\
\text { turning to left- } 2 \text { episodes. All } \\
\text { episodes on } 18 \text { Jan } 83 \text {. }\end{array}$ & $\begin{array}{l}\text { Rt fronto- } \\
\text { parietal slowing } \\
\text { with } \\
\text { dysrhythmia. }\end{array}$ & $\begin{array}{l}\text { Decrease attenuation lesion in right } \\
\text { frontal region with ring like } \\
\text { enhancement. (CT } 22 \text { Jan } 83 \text { ). }\end{array}$ & $\begin{array}{l}\text { Asymptomatic } \\
\text { Repeat CT } \\
9 \text { Mar, } 22 \text { Mar, } \\
6 \text { Apr } 83 \text {. } \\
\text { Graded } \\
\text { clearance. }\end{array}$ \\
\hline & 11 & $\mathbf{M}$ & $\begin{array}{l}\text { Episode starting Lt hand clonic } \\
\text { convulsion; later generalised } \\
\text { tonic/clonic convulsions } 5 \text { to } 6 \text {. } \\
\text { Postictal Lt arm weakness } 1 / 2 \mathrm{hr} \\
\text { temp } 99^{\circ} \mathrm{F} \text {. First epidose } 22 \text { Jan } 84 \\
\text { and last } 24 \text { Jan } 84 \text {. }\end{array}$ & Not done. & $\begin{array}{l}\text { Increased area of attenuation } \\
\text { surrounded by low attenuation. } \\
\text { (CT } 31 \text { Jan 84). }\end{array}$ & $\begin{array}{l}\text { Asymptomatic. } \\
\text { Repeat CT } \\
\text { clear. } \\
\text { (30 Apr } 84) \text {. }\end{array}$ \\
\hline
\end{tabular}

CSF done -NAD

Individual declined admission but had follow up scans in an another hospital. Repeat Ct scan 16 Apr 83. Complete clearance.

EEG showed generalised bursts of spike/slow wave discharges bilaterally. CT scan on 14 September 1983 showed a low attenuation lesion in the right fronto-parietal region. The child was given phenobarbitone $30 \mathrm{mgm}$ twice a day and has remained asymptomatic. A repeat CT scan after 20 weeks showed complete disappearance of the earlier CT findings (fig $2 \mathrm{ab}$ ).

\section{Case 3}

A 34-year-old female presented with generalised seizures on 16 October 1983 with postictal prolonged confusion and postictal weakness of the right hand which recovered in the next four hours. She had another generalised seizure on 18 October 1983 with postictal prolonged confusion and vomiting. She continued to have left sided headache and projectile vomiting. Examination was normal except that she looked apprehensive, depressed and had repeated yawning. Fundi were normal. A diagnosis of late onset seizures with Todd's paresis on the right side was made and an intracranial space occupying lesion was suspected. She was put on phenobarbitone $30 \mathrm{mgm}$ morning and $60 \mathrm{mgm}$ at night. Blood count, urinalysis, skull thigh and chest radiographs were normal. EEG showed slowing in the left sided leads (monopolar run) with occasional spikes. CT scan showed a high attenuation lesion with perifocal oedema in the left posterior temporal region. Her headache and vomiting subsided in a week and she became asymptomatic. In view of vomiting and headache, an intracranial space occupying lesion was strongly suspected and she was given steroids initially for a week. She became asymptomatic and repeat scan eight weeks later showed gradual clearance of the lesion, so it was decided to follow the patient with repeat CT scans. CT scan 24 weeks later showed complete clearance of the lesion (fig $3 \mathrm{ab}$ ). 

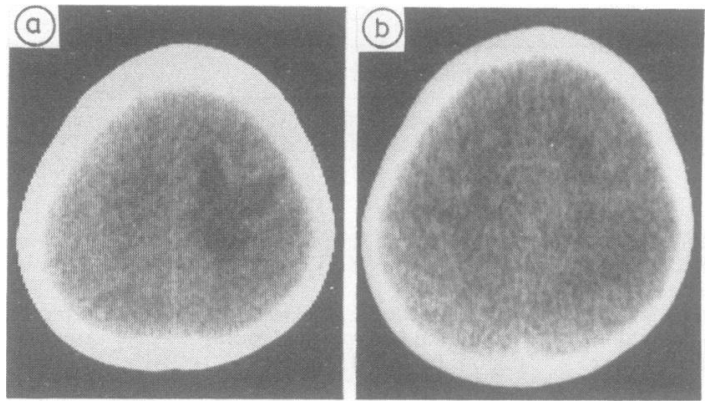

Fig 2 (a) Showing low attenuating lesion in right parietal region. (b) Showing complete disappearance of this lesion on follow up CT.
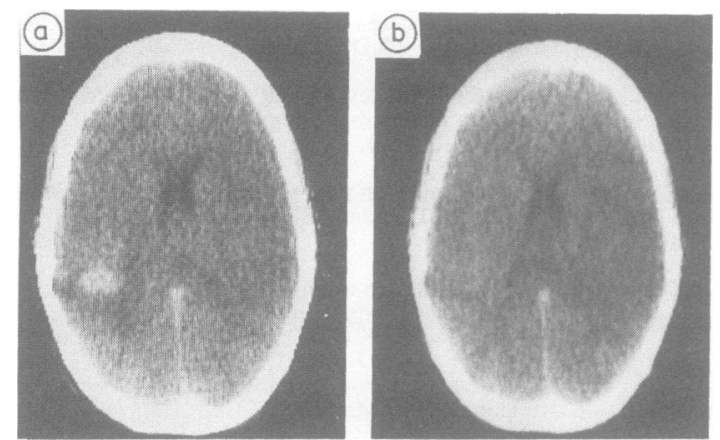

Fig 3 Enhanced Scans. (a) High attenuating lesion with perifocal oedema in left post-temporal region laterally placed. (b) Repeat scan showing complete clearance of lesion.
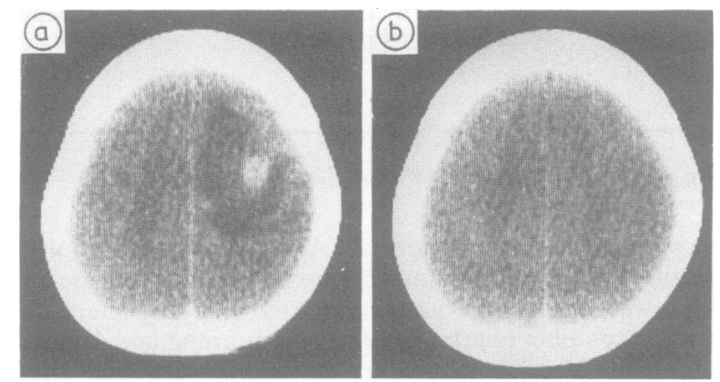

Fig 4 (Case No 11) Enhanced Scans. (a) Disc area of increased attenuation surrounded by low attenuation area in right parietal region. (b) Shows complete disappearance of this lesion in follow up scans.

\section{Discussion}

Over one year we encountered 11 cases with CT abnormalities (both low attenuation and mixed) after seizures, which subsequently disappeared What are the clinico-CT scan correlates of thes attenuations, what is their pathology and what does their disappearance imply?

It is their disappearance without any specifi therapy (except anticonvulsants) which is intriguing It can be concluded that whatever the underlyin pathology or pathophysiological changes respons ible for the appearance of these lesions, the process is ultimately reversible. Therefore, congenital disor $\overline{\bar{\sigma}}$ ders, tumours, and degenarative disease are unlikel causes. Trauma also can be excluded as there was nE history of head injury. The clinical setting an $\bar{\Phi}$ results of investigations and follow up also strongl argue against trauma, vascular diseases and infecon tion.

Several studies ${ }^{2-8}$ are available dealing with $C \vec{B}$ scans in patients with various type of seizures. Gas $=$ taut and Gastaut, ${ }^{2}$ reported findings of CT in 401 of 500 consecutive patients with epilepsy. $90 \%$ hat normal CT and were classed under primary generaf ised epilepsy, while the rest had abnormal CT scans so were classed as secondary epilepsy. With organifo lesions, (tumour, trauma, ischaemia and infectionio etc.) CT was considered to have markedly increased the ability to establish the aetiology. In anothes series, 150 patients with seizure disorder were analysed in detail. Of these 60 patients had abnories mal scans. These abnormalities included atrophy (focal 13, diffuse 20), porencephaly (4), h\&d rocephalus (5), vascular abnormalities (6), inforct (6), and neoplasm (6). In these series ${ }^{2-8}$ not a sing case of seizures with disappearing CT scan attentaes tion was reported.

Theoretically some of the cases of the present series may be due to infarction or rupture of a sma零 angioma. Gastaut et al ${ }^{4}$ emphasised that Jacksonia seizures may herald Sylvian infarctions, as revealed by computed tomography. Out of a population of 942 adult epileptics examined with CT they found Sylvian infarction in 17 patients without any priog history of cerebrovascular accident. In most of these cases vascular occlusion was confirmed by carotif angiography. In the majority, however, there was. post-ictal neurological abnormality for hours or days. and in one third of the cases there was persistence of neurological deficit and/or Jacksonian seizures. Is none of our cases except one with focal deficit pres ent, and this subsequently disappeared. Further, i $\$$ all Gastaut's cases there was CT scan evidence of low attenuation in areas corresponding with Sylviats infarction. In the present series the involved area was not necessarily Sylvian and in some cases there was increased as well as low attenuation. Further the complete disappearance of the CT abnormalities in our patients differs from the CT scan changes due 
to infarction, which would persist and do not disappear totally.

The possibility of cryptic malformation must be considered. $^{10}$ These are commonly present with intracranial haemorrhage which was not present in our cases. Further, although CT scan may not reveal these cryptic vascular malformations (microangioma), the resultant haematoma points out to the underlying pathology.

The disappearance of CT scan attenuations without any specific therapy excludes most forms of infective pathology. Cysticercosis or tuberculoma as a cause of seizures is not so uncommon in this geographical region, but neither is likely to be the cause of the CT scan abnormalities discussed here, because the latter disappeared without specific therapy. Bhargava and Tandon," studied in CNS tuberculosis in 55 cases and described a special group of 17 cases. This group of 17 patients, mostly children and young adults, presented with focal seizures with or without generalisation or associated postictal deficit but without evidence of raised intracranial pressure. On CT scan they had small disc or ring lesions. Antituberculous treatment appeared to clear the lesion on the CT scan promptly.

In view of the above discussion one wonders whether the responsible pathological lesion may not be structural but functional. Seizures may produce cerebral oedema. Meera, Goulatia and Bhargava ${ }^{12}$ in CT analysis of 525 patients reported 20 cases of seizures of late onset with or without papilloedema but with no focal neurological deficit, which were reported to have diffuse white matter oedema varying in absorption values from 5-15 HU and with small midline ventricles. Focal low attenuation areas seen in CT scan in our cases corresponded very well with the focal seizures and may be explained by postictal oedema akin to postictal EEG slowing. Their disappearance after appropriate anticonvulsant therapy with control of seizure may also support this hypothesis of postictal oedema. But how does one explain high attenuating lesion surrounded by low attenuated area in some of these cases? Moreover, we have encountered patients presenting with a status epilepticus with CT scans which are normal. Several reports ${ }^{2-7}$ have not described any CT scan changes in seizures per se.

Accordingly, the changes we have described may not simply be the result of focal seizures. Prior to CT scanning, such focal seizures might be attributed to missed tuberculoma or cysticercosis, which could have escaped detection using cerebral angiography or pneumoencephalography. The CT scan findings, and the subsequent recovery, do not suggest such diagnoses. Alternatively, the changes described could be a form of focal encephalitis, perhaps peculiar to this region.

In conclusion, if a patient presents with seizures and the sort of CT scan findings discussed here, without signs of raised intracranial pressure or CT scan evidence of mass effect, it appears wise to wait and repeat the CT scan instead of starting prolonged antituberculous therapy or subjecting him to invasive procedures and surgery.

We are grateful to Maj Gen JM Grover, AVSM, the Commandant, Army Hospital, for constant encouragement and the Director General, Armed Forces Medical Services for permission to publish this article.

\section{References}

I Valentine AR, Pullicino P, Bannan E. A Practical Introduction to Cranial CT. London: William Heinemann. Medical Booke Ltd, 1981:137.

${ }^{2}$ Gastaut H, Gastaut JL. Computerized transverse axial tomography in epilepsy. Epilepsia 1976;17:325-36.

${ }^{3}$ Bauor G, Mayr U, Pallua A. Computerized axial tomography in chronic partial epilepsies. Epilepsia 1980; 21:227-33.

${ }^{4}$ Bordanoff BM, Stafford CR, Green L, et al. Computerized transaxial tomography in the evaluation of patient with focal epilepsy. Neurology (Minneap) 1975;25: 1013-7.

${ }^{5}$ Gall MV, Becker H, Hacker H. Computerized transverse axial tomography in epilepsy. Epilepsia 1976; 17:340-1.

- Scollo-Lavizzari G, Eichhorn K, Wuthrich R. Computerized transverse axial tomography in the diagnosis of epilepsy. Eur Neurol 1977;15:5-8.

${ }^{7}$ McGahan JP, Dublin AB, Hill RP. The evaluation of seizure disorders by computerized tomography. J Neurosurg 1979;50:328-32.

${ }^{8}$ Russo LS, Goldstein KH. The diagnostic assessment of single seizures. Arch Neurol 1983;40:744-6.

${ }^{9}$ Gastaut H, Boudouresques G, Gastaut JL, et al. Jacksonian epileptic seizures as inaugural manifestations of sylvian infarction revealed by computerized axial tomography. In: du Boulay GH, Moseley IF, eds. The First European Seminar on Computerized Axial Tomography in clinical practice. New York: Springer-Verlag, 1977:237-242.

${ }^{10}$ Prakash B, Beohar PC, Misra RC. Low flow (cryptic) arteriovenous malformation and spontaneous haematoma. Acta Neurochir (Wein) 1983;69:61-67.

"Bhargava S, Tandon PN. CNS Tuberculosis-Lessons learnt from CT studies. Neurology India 1980;28:207-12.

12 Meera RI, Goulatia RK, Bhargava S. CT anaylsis of first 525 patients. Neurology India 1980;17:86-94. 